\title{
Incorporation of Lactobacillus casei in Iranian ultrafiltered Feta cheese made by partial replacement of $\mathrm{NaCl}$ with $\mathrm{KCl}$
}

\author{
R. Karimi, ${ }^{*}$ A. M. Mortazavian, ${ }^{* 1}$ and M. Karami $\dagger$ \\ *Department of Food Science and Technology, National Nutrition and Food Technology Research Institute, Faculty of Nutrition \\ Sciences and Food Technology, Shahid Beheshti University of Medical Sciences, PO Box 19395-4741, Tehran, Iran \\ †Department of Food Science and Technology, Islamic Azad University, Kermanshah Branch, Kermanshah, Iran
}

\begin{abstract}
Probiotic Iranian ultrafiltered Feta cheese was produced from ultrafiltration of milk with a volumetric concentration factor of 4.5:1. The heat-treated retentates were inoculated with $10^{7}$ cfu of Lactobacillus casei LAFTI L26/mL. A mesophilic-thermophilic mixed culture of Lactococcus lactis ssp. lactis, Lactococcus lactis ssp. cremoris, and Streptococcus thermophilus was also used. Three percent (wt/wt) salt with different ratios of $\mathrm{NaCl}: \mathrm{KCl}(100 \% \mathrm{NaCl}, 50 \% \mathrm{NaCl}: 50 \% \mathrm{KCl}, 75 \%$ $\mathrm{NaCl}: 25 \% \mathrm{KCl}$, and $25 \% \mathrm{NaCl}: 75 \% \mathrm{KCl}$ ) were used in cheese formulation. The viability of $L$. case $i$ was determined in treatments during the ripening period $(90 \mathrm{~d}$ at $5^{\circ} \mathrm{C}$ ) within $15-\mathrm{d}$ intervals. The $\mathrm{pH}$, titratable acidity, and redox potential changes were monitored throughout the mentioned period. The mean $\mathrm{pH}$ drop rate, mean acidity increase rate, and mean redox potential increase rate were calculated at the end of the storage period. Also, total nitrogen, water-soluble nitrogen, lactic acid, and acetic acid concentrations, and syneresis and sensory characteristics of the product were measured during the mentioned period every $30 \mathrm{~d}$. The maximum viability of $L$. case $i$ was observed within $\mathrm{d}$ 15 to 30 of the ripening period in the treatment containing the lowest amount of sodium. Addition of $\mathrm{KCl}$ enhanced syneresis. Cheeses with $\mathrm{NaCl}$ alone and with only $25 \%$ replacement by $\mathrm{KCl}$ have the highest sensory acceptability.
\end{abstract}

Key words: Lactobacillus casei, potassium chloride, probiotic, ultrafiltered Feta cheese

\section{INTRODUCTION}

Probiotics are defined as "live microorganisms, which when administered in adequate numbers, confer a health benefit on the host" (FAO/WHO, 2001). Probi-

\footnotetext{
Received August 25, 2011.

Accepted March 16, 2012.

${ }^{1}$ Corresponding author: mortazvn@sbmu.ac.ir or mortazvn@yahoo.
} com otic dairy products are the main food group for delivery of probiotics into the gastrointestinal tract (Granato et al., 2010). Cheese provides a valuable alternative compared with fermented milks and yogurt as a food vehicle for probiotic delivery and as a result has been the subject of various research and marketing studies in recent years (Gomes da Cruz et al., 2009; Ibrahim et al., 2010; Karimi et al., 2011). It creates a buffer against the highacidic environment in the gastrointestinal tract (GIT) and, thus, creates a more favorable environment for probiotic survival throughout gastric transit (Corbo et al., 2001; Sharp et al., 2008; Modzelewska-Kapituła et al., 2010; Madureira et al., 2011a; Karimi et al., 2012). Also, cheese has higher $\mathrm{pH}$, more solid consistency, and relatively higher fat content compared with fermented milks such as yogurt (Boylston et al., 2004; Ong et al., 2006). A prerequisite of probiotic cheese manufacture is that the cultures survive the relatively long cheese ripening and storage times, a factor that should be taken into account when selecting probiotic strains for cheese applications (Tamime et al., 2005). Probiotic microorganisms should remain viable in a minimum level per gram or milliliter of product until the time of consumption. This actual amount (that is known as viability) generally varies from $10^{6}$ to $10^{7} \mathrm{cfu} / \mathrm{g}$ per milliliter according to different guidelines and literature (Talwalkar and Kailasapathy, 2004; Tamime et al., 2005; ISIRI, 2008; Korbekandi et al., 2011). For different cheeses, the minimum level of $10^{7} \mathrm{cfu} / \mathrm{mL}$ has been generally approved (Ishibashi and Shimamura, 1993; De Vuyst, 2000). To achieve this criterion, changes in the numbers of viable bacteria during the ripening and storage period should be known. Various compositional and process factors significantly affect the viability of probiotic microorganisms in cheese, including $\mathrm{pH}$, titratable acidity, redox potential, bacteriocins, flavoring agents, microbial competitions, packaging materials, rate of inoculation, supplementation of milk with nutrients, incubation temperature, storage temperature, addition of salt, and antimicrobial preservatives (Tamime et al., 2005; Champagne and Rastall, 2009; Albenzio et al., 2010; Fritzen-Freire et al., 2010a,b; 
Gomes et al., 2011a; Karimi et al., 2011; Madureira et al., 2011b). Additionally, salt type and percentage possess remarkable affects on the viability of probiotics (Gomes et al., 1998, Kasımoğlu et al., 2004) and the viability of probiotic strains in cheese is restricted by the presence of salt (Yllmaztekin et al., 2004). In the case of functional cheeses containing probiotic bacteria, the viability of probiotic bacteria is drastically decreased in cheeses with salt concentration over $4 \%$. For this reason, cheeses that naturally contain high concentrations of sodium need to have their production process optimized to incorporate functional characteristics (Gomes da Cruz et al., 2009). Whereas the viability of probiotics in dry salted cheese varieties has been extensively studied (Ghoddusi and Robinson, 1996; Gomes and Malcata, 1998; Gobbetti et al., 1998; Gomes et al., 1998; Guinee, 2004; Yllmaztekin et al., 2004; Tamime et al., 2005, 2006; Özer et al., 2008; Gomes da Cruz et al., 2009), limited data are available on the probiotic viability in cheeses salted with the mixture of $\mathrm{NaCl}$ and $\mathrm{KCl}$. Lactobacillus casei is consumed worldwide as a probiotic supplement in yogurt and other foods. This species grows in cheese and persists at high populations for months during ripening or storage (Cogan et al., 2007).

During the past $30 \mathrm{yr}$, the use of ultrafiltered milk for cheesemaking has attracted considerable attention throughout the world (El-Gazzar and Marth, 1991; Renner and Abd El-Salam, 1991; Cheryan and Alvarez, 1995; Kosikowski and Mistry, 1997; Cheryan, 1998). Ultrafiltration has been successfully applied in Feta cheesemaking (Tamime and Kirkegaard, 1991). Iranian UF Feta cheese made from bovine milk is manufactured in modern dairy plants from UF and pasteurized milk (Karami et al., 2009a) with mesophilic and thermophilic starter cultures and commercial microbial rennet. The main characteristics of this cheese type are a minimum of $36 \%$ (wt/wt) TS, protein content of $11 \%$, fat content of $15 \%, 27$ degrees Brix ( $\left.{ }^{\circ} \mathrm{Bx}\right)$, maximum titratable acidity of 42 Dornic degrees $\left({ }^{\circ} \mathrm{D}\right), \mathrm{pH}$ of 6.20 to 6.65 , and maximum salt content of $4 \%$ (Karami et al., 2009a,b).

Various studies have indicated that an increased intake of potassium via the diet can exert a protective effect in individuals with sodium-induced hypertension, reduces urinary calcium excretion, potentially protects skeletal mass (Karagözlu et al., 2008), and prevents the incidence of kidney stones (Goulding, 1997). As cheese consumption is increasing worldwide, reduction of salt as a sodium carrier (without affecting its acceptability) needs to be taken into consideration (Johnson et al., 2009; Agarwal et al., 2011; Cruz et al., 2011; Drake et al., 2011). Low-sodium dairy products are those in which sodium chloride is partially (normally, more than $25 \%$ ) replaced by other salt sources. Potassium chloride or a mixture of $\mathrm{NaCl}$ and $\mathrm{KCl}$ with $\mathrm{NaCl}$ have been the most widely and successfully used partial replacement for $\mathrm{NaCl}$ in different cheeses (Ayyash et al., 2011; Gomes et al., 2011b) including Feta cheese (Aly, 1995; Katsiari et al., 1997, 2000a). However, in none of them has the detailed effect of salt replacement on the viability of probiotics been studied. Additionally, the sensory effect of probiotic UF Feta cheese with substituted salts has not been extensively studied. The aim of this study was to consider the physical, chemical, microbiological and sensory characteristics of probiotic Iranian UF Feta cheese produced with added $L b$. case $i$ LAFTI L26 and adjunct cultures of Lactococcus lactis ssp. lactis, Lc. lactis ssp. cremoris, and Streptococcus thermophilus, by partial replacement of $\mathrm{NaCl}$ with $\mathrm{KCl}$, during $90 \mathrm{~d}$ of storage at $5^{\circ} \mathrm{C}$.

\section{MATERIALS AND METHODS}

\section{Starter Culture and Probiotic Organism}

Freeze-dried mixed mesophilic-thermophilic culture (blend of Lc. lactis ssp. lactis, Lc. lactis ssp. cremoris and Strep. thermophilus MTF1) was obtained from DI-PROX (Levallois, Paris, France). Direct Set Lyophilized L. casei LAFTI L26 (Delvo; >1 U/1,000 L) was obtained from DSM Food Specialties (Moorebank, NSW, Australia).

\section{Other Cheese Production Materials}

Rennet (Milase) was supplied by Ceska-lase (CSK Food Enrichment, Nieuwegein, the Netherlands). Raw cow milk, equipment, and filtration moduli were provided by PAK-ARA Dairy Complex (Sanandaj, Kurdistan, Iran).

\section{Cheese Manufacture}

Iranian UF Feta cheese samples were produced according to Karami et al. (2009a). After separation of fat and microfiltration, skim milk and fat were recombined up to $3.5 \%$ fat. Then, heat treatment $\left(74^{\circ} \mathrm{C}\right.$ for 15 s) and UF (Invensys APV, Primodan, Pasteursvej, Silkeborg, Denmark) in 3 consecutive loops were done (loop 1, 2, and 3 contained 12, 9, and 6 filters and every loop concentrated milk Brix up to 16, 21, and 28, respectively). The total volume concentration factor was $4.5 \mathrm{~kg}$ of milk to $1.0 \mathrm{~kg}$ of retentate. A pressure of $55 \times$ $10^{5} \mathrm{~Pa}$ at $50^{\circ} \mathrm{C}$ for $2 \mathrm{~s}$ was exerted for homogenization. The retentate was pasteurized at $79^{\circ} \mathrm{C}$ for $10 \mathrm{~s}$. Then, 
retentate was cooled down to $36^{\circ} \mathrm{C}$. In 4 separate stirrer tanks, rennet (50 g for $1,000 \mathrm{~kg}$ of retentate), cheese starter (13 g for $1,000 \mathrm{~kg}$ of retentate), L. casei L26 $\left(10^{10} \mathrm{cfu} / \mathrm{g}\right.$ for $1,000 \mathrm{~kg}$ of retentate $)$, and calcium chloride $(0.02 \% \mathrm{wt} / \mathrm{wt})$ were mixed with water individually. The titratable acidity of the starter culture suspension was (mean $\pm \mathrm{SD}) 6.65 \pm 0.05^{\circ} \mathrm{D}$. Then, the components were remixed and finally $15 \mathrm{~mL}$ of mixture was added to each cheese container while dosing the retentate simultaneously. Before dosing, $10 \mathrm{mg} / \mathrm{kg}$ of anti-foaming and $15 \mathrm{mg} / \mathrm{kg}$ of anti-sticking agents were added to each cheese container (1,000-g polystyrene containers). In a coagulation tunnel $\left(37^{\circ} \mathrm{C}\right.$ for $\left.20 \mathrm{~min}\right)$, retentate was converted to a pre-cheese mixture. In a sealing machine (Primodan), 3\% dry salt $(100 \% \mathrm{NaCl}, 50 \%$ $\mathrm{NaCl}: 50 \% \mathrm{KCl}, 75 \% \mathrm{NaCl}: 25 \% \mathrm{KCl}$, or $25 \% \mathrm{NaCl}: 75 \%$ $\mathrm{KCl}$ ) was placed on the parchment paper on the top of cheese. Food-grade $\mathrm{NaCl}$ and $\mathrm{KCl}$ (E508; Merck KGaA, Darmstadt, Germany) were used. Finally, the containers were sealed using aluminum foil. The thickness of polystyrene containers and aluminum foil were 450 and $40 \mu \mathrm{m}$, respectively. In the preripening stage (at $37^{\circ} \mathrm{C}$ for about $36 \mathrm{~h}$ ), the cheese $\mathrm{pH}$ decreased to 4.8 and then samples were transferred to a cold room $\left(6 \pm 1^{\circ} \mathrm{C}\right)$ for the ripening period $\left(3\right.$ to $90 \mathrm{~d}$ at $\left.5^{\circ} \mathrm{C}\right)$.

\section{Chemical Analysis}

Cheese samples were analyzed for moisture by heating at $102^{\circ} \mathrm{C}$ to constant weight according to the method of the Association of Official Analytical Chemists (AOAC, 1990; method 926.08), fat content by the Gerber method (BSI, 1995), and salt content by Mohr titration (Karagözlu et al., 2008).

A Knick 766 Calimatic pH meter (Knick Lab Instruments, Niels Bohrweg, Utrecht, the Netherlands) was used for measurement of $\mathrm{pH}$ and redox potential of cheese samples. Cheese slurry was prepared by blending $20 \mathrm{~g}$ of grated cheese with $12 \mathrm{~mL}$ of $\mathrm{H}_{2} \mathrm{O}$ and before measurement, the $\mathrm{pH}$ meter was calibrated with fresh $\mathrm{pH} 4.0$ and 7.0 standard buffers. The titratable acidity was determined after mixing $20 \mathrm{~g}$ of sample with 250 $\mathrm{mL}$ of distilled water, filtration through Whatman \#1 filter paper, and titrating $25 \mathrm{~mL}$ of filtrated sample with $0.1 \mathrm{~N} \mathrm{NaOH}$ using $0.5 \%$ phenolphthalein (ISIRI, 2001; Mortazavian et al., 2010).

Total nitrogen ( $\mathbf{T N}$ ) was determined by applying the Kjeldahl method as one of the indices for the progress in the proteolysis reaction during the ripening period (IDF, 1993). Water-soluble nitrogen (WSN) was measured as the second index of the proteolysis reaction (Alizadeh et al., 2006; Karami et al., 2009a). In this method, $20 \mathrm{~g}$ of cheese sample was homogenized with $100 \mathrm{~mL}$ water in a stomacher for 5 min and the suspen- sion was incubated at $40^{\circ} \mathrm{C}$ for $1 \mathrm{~h}$, after which the insoluble solids were separated by centrifugation at $4^{\circ} \mathrm{C}$ for $30 \mathrm{~min}$ at $1,500 \times \mathrm{g}$. The supernatant was then filtered through glass wool and TN was measured using the Kjeldahl method. All mentioned analyses were performed in triplicate. The $\mathrm{pH}$, titratable acidity, and redox potential were analyzed during $90 \mathrm{~d}$ of ripening time, every $15 \mathrm{~d}$. Total nitrogen and WSN were measured during this period every $30 \mathrm{~d}$.

Parameters of mean $\mathrm{pH}$ drop rate, mean acidity increase rate, and mean redox potential increase rate were calculated as follows (Mortazavian et al., 2010; Shafiee et al., 2010; Heydari et al., 2011):

$$
\begin{gathered}
\mathrm{pH} \text { drop rate }=(\text { final } \mathrm{pH} \text { value }- \text { initial } \mathrm{pH} \text { value }) / \\
\text { storage time }(\mathrm{pH} \text { value } / \mathrm{d})
\end{gathered}
$$

acidity increase rate $=($ final acidity value - initial acidity value)/storage time $\left({ }^{\circ} \mathrm{D} / \mathrm{d}\right)$;

redox potential increase rate $=($ final value

$$
\text { - initial value)/storage time }(\mathrm{mV} / \mathrm{d}) \text {. }
$$

Quantification of lactic and acetic acids was carried out by HPLC (CE 4200 instrument; Cecil Instruments Ltd., Milton Technical Center, Cambridge, UK) according to Mortazavian et al. (2010). Briefly, for extraction of acids, $4.0 \mathrm{~g}$ of sample was diluted to $25 \mathrm{~mL}$ with 0.1 $\mathrm{N} \mathrm{H}_{2} \mathrm{SO}_{4}$, homogenized and centrifuged at 5,000 $\times g$ for $10 \mathrm{~min}$. The supernatant was filtered through Whatman \#1 filter paper and through a $0.20-\mu \mathrm{m}$ membrane filter, and was immediately analyzed. A Jasco UV-980 detector and a Nucleosil $100-5 \mathrm{C}_{18}$ column (MachereyNagel GmbH \& Co. KG, Duren, Germany) were used. The mobile phase was $0.009 \mathrm{~N} \mathrm{H}_{2} \mathrm{SO}_{4}$ at a flow rate of $0.5 \mathrm{~mL} / \mathrm{min}$. The wavelength of detection was optimized at $210 \mathrm{~nm}$. The standard solutions of lactic and acetic acids (Merck KGaA) were prepared in distilled water. The retention times for lactic and acetic acids were 3.45 and $3.58 \mathrm{~min}$ and the standard curve regression coefficients were 0.989 and 0.991 , respectively.

\section{Syneresis}

Syneresis (g/100 g) was calculated as the weight of whey (in grams) separated from each cheese in its package after the different storage times divided by the weight of cheese of the same package (in grams) and multiplied by 100 (Buriti et al., 2005). The whey was separated at room temperature by inversing the containers until full drip loss was done. 


\section{Microbiological Analysis}

Cheese samples were collected at 15-d intervals during $3 \mathrm{mo}$ of storage. Ultrafiltered Feta cheese samples $(25 \mathrm{~g})$ were diluted in $225 \mathrm{~mL}$ of sterile $2 \%$ (wt/vol) trisodium citrate (Merck KGaA) at $40^{\circ} \mathrm{C}$. The sample was macerated in a stomacher 400 laboratory blender (Seward Medical, London, UK) for 4 min at high speed in stomacher bags to obtain slurry for the first dilution and subsequent serial dilutions were performed in $0.15 \%$ (wt/vol) peptone and water solution (Merck KGaA; Vinderola et al., 2009). Appropriate dilutions were pour plated. Lactobacillus casei was selectively enumerated using de Man, Rogosa, and Sharpe (MRS)-bile agar (MRS agar by Merck KGaA and bile by Sigma-Aldrich Corp., St. Louis, MO; Vinderola and Reinheimer, 1999; Bergamini et al., 2005; Mortazavian et al., 2007). The plates were incubated aerobically at $37^{\circ} \mathrm{C}$ for $72 \mathrm{~h}$. Neither thermophilic nor mesophilic bacteria grew in the presence of bile salts at $37^{\circ} \mathrm{C}$. Viability of $L b$. case $i$ was assessed every $15 \mathrm{~d}$.

The viability proportion index (VPI) of probiotic microorganism at each interval was calculated as follows (Mortazavian et al., 2010, 2011; Shafiee et al., 2010; Heydari et al., 2011).

$$
\begin{aligned}
& \text { VPI = final cell population }(\mathrm{cfu} / \mathrm{mL}) / \text { initial cell } \\
& \text { population }(\mathrm{cfu} / \mathrm{mL})
\end{aligned}
$$

\section{Sensory Evaluation}

The sensory test was designed according to the International Organization for Standardization and International Dairy Federation (ISO, 2009). A panel of 7 men and 7 women consisting of staff and postgraduate students of the Shahid Beheshti University of Medical Sciences (Tehran, Iran), who were preselected as regular cheese consumers (daily or at least weekly) and familiar with Iranian UF Feta cheese, evaluated the cheeses. Two replications for 2 separately produced trials were performed. A complete block design was used. The attributes assessed were flavor, texture, appearance, and general acceptability, for each of which the cheeses were awarded points on a scale of 0 (very poor) to 5 (very good). Panelists were also asked to list defects, if any were detected. The cheese samples were cut into standard bite-size pieces of about $1 \mathrm{~cm}^{3}$. Cheese pieces were placed into airtight plastic containers and conditioned at room temperature for $2 \mathrm{~h}$ before evaluation with a consumer sensory evaluation questionnaire and randomly coded with 3 -digit numbers. Water was used for mouth rinsing between samples. Each cheese was evaluated in duplicate. Cheeses were subjected to periodic sensory analysis throughout ripening $(3,30$, 60 , and $90 \mathrm{~d}$ ).

\section{Statistical Analysis}

Experiments were performed in triplicate and the ranked orders of means were determined at a significance level of $0.05(P<0.05)$ using a 2 -way ANOVA from Minitab software (Minitab Inc., State College, PA). The design was a completely randomized design.

\section{RESULTS}

\section{Chemical and Biochemical Characteristics}

Compositional Characteristics and Proteolysis. Table 1 shows the contents of moisture, TN/ $\mathrm{DM}$, fat in DM, and total salt in different treatments. No significant differences $(P>0.05)$ were observed among the treatments. The results agreed with those of other workers (Aly, 1995; Katsiari et al., 1997, 2000b) who indicated that the Feta cheeses made with these $\mathrm{NaCl}: \mathrm{KCl}$ mixtures exhibited no significant $(P>0.05)$ differences in compositional (moisture, fat, protein, and total salt) properties in comparison with the control cheese.

Proteolysis plays a critical role in determining the typical sensory characteristics and represents a significant indicator of quality (flavor and texture). For example, a positive and significant correlation exists between the scores of bitterness and the level of WSN (Lee et al., 1999; Ong et al., 2007). Also, proteolytic products formed during ripening stimulate the growth of probiotic bacteria such as Lb. casei (Nath and Ledford, 1973; Bergamini et al., 2009). Proteolysis is caused by indigenous milk enzymes (plasmin), rennet (pepsin and chymosin), and microbial enzymes released by starter cultures (Fox and McSweeney, 1996). Plasmin, as the most significant alkaline milk indigenous proteinase, dissociates from the micelles as the $\mathrm{pH}$ is reduced (Sousa et al., 2001; Nielsen, 2002; Visser and van den Berg, 2002). Although plasmin makes little contribution to proteolysis (Rao et al., 1989), the lower $\mathrm{pH}$ causes higher dissociated plasmin and this, consequently, results in higher WSN/TN percentage (Farkye and Fox, 1992). Apart from plasmin, the peptidases of Lb. casei ssp. casei, which is quite insensitive to $\mathrm{pH}$ and not very sensitive to $\mathrm{NaCl}$ (Gobbetti et al., 1999), can contribute to the WSN formation. In most cheese varieties, the initial hydrolysis of caseins is caused by the rennet and, to a lesser extent, by plasmin and perhaps somatic cell proteinases (e.g., cathepsin D; McSweeney, 2004). Ong et al. (2006), in their study on Cheddar cheese, found that the level of proteolysis was particu- 
Table 1. Moisture, total nitrogen (TN)/DM, fat in DM (FDM), and salt contents during the storage time ${ }^{1}$

\begin{tabular}{|c|c|c|c|c|c|}
\hline $\begin{array}{l}\text { Storage } \\
\text { time (d) }\end{array}$ & $\begin{array}{l}\text { Treatment } \\
(\mathrm{NaCl}: \mathrm{KCl})\end{array}$ & Moisture (\%) & $\mathrm{TN} / \mathrm{DM}(\%)$ & FDM $(\%)$ & Salt (\%) \\
\hline \multirow[t]{4}{*}{3} & 100:0 & 64.27 & 6.25 & 40.11 & 3.01 \\
\hline & 50:50 & 64.35 & 6.23 & 40.12 & 3.00 \\
\hline & $75: 25$ & 64.31 & 6.23 & 40.11 & 3.02 \\
\hline & $25: 75$ & 64.19 & 6.22 & 40.04 & 3.02 \\
\hline \multirow[t]{4}{*}{30} & 100:0 & 64.21 & 6.25 & 40.08 & 2.99 \\
\hline & $50: 50$ & 64.35 & 6.22 & 40.04 & 2.98 \\
\hline & $75: 25$ & 64.22 & 6.23 & 40.08 & 2.98 \\
\hline & $25: 75$ & 64.11 & 6.19 & 40.01 & 2.97 \\
\hline \multirow[t]{4}{*}{60} & 100:0 & 64.13 & 6.21 & 40.05 & 2.97 \\
\hline & $50: 50$ & 63.61 & 6.18 & 39.96 & 2.97 \\
\hline & $75: 25$ & 64.09 & 6.18 & 40.02 & 2.97 \\
\hline & $25: 75$ & 63.44 & 6.15 & 39.91 & 2.95 \\
\hline \multirow[t]{4}{*}{90} & 100:0 & 63.89 & 6.15 & 39.98 & 2.96 \\
\hline & $50: 50$ & 63.21 & 6.11 & 39.94 & 2.94 \\
\hline & $75: 25$ & 63.86 & 6.13 & 39.97 & 2.95 \\
\hline & $25: 75$ & 62.95 & 6.09 & 39.88 & 2.92 \\
\hline
\end{tabular}

${ }^{1}$ No significant differences were found within any of the parameters within a storage day $(P>0.05)$.

larly high in cheeses with the addition of $L b$. casei 279 and Lactobacillus paracasei LAFTI L26 in the presence of $\mathrm{NaCl}$ (Ong et al., 2006).

Figure 1 shows the proportion of WSN to total nitrogen $(\mathrm{WSN} / \mathrm{TN})$ in treatments during the ripening period $\left(90 \mathrm{~d}\right.$ at $\left.5^{\circ} \mathrm{C}\right)$. According to this figure, after $45 \mathrm{~d}$ of storage, cheese samples with higher content of $\mathrm{KCl}$ had a higher WSN/TN percentage (in parallel with lower $\mathrm{pH}$ values; Table 2). The levels of WSN/ $\mathrm{TN}$ in cheeses with addition of $25 \% \mathrm{NaCl}$ and $75 \%$ $\mathrm{KCl}$ were significantly higher than other samples during $90 \mathrm{~d}$ of storage. The WSN in the sample with the proportion of 100:0 ( $\mathrm{NaCl}: \mathrm{KCl})$ was at the lowest value. Therefore, the inhibitory effect of $\mathrm{KCl}$ on proteolytic enzymes must have been weaker than $\mathrm{NaCl}$. This result agreed with those of other investigators for Feta, Cheddar, Kefalograviera, and White cheese salted with $\mathrm{NaCl}: \mathrm{KCl}$ (Rasmussen and Barbano, 1987; Aly, 1995; Güven and Karaca; 2001; Katsiari et al., 2001). It has been reported that the activity of plasmin is inhibited by a concentration of $\mathrm{NaCl}$ higher than $2 \%$ (Noomen, 1978). In treatments with higher amounts of $\mathrm{KCl}$ compared with $\mathrm{NaCl}, L b$. casei cells must be more active, resulting in greater proteolysis. It should be pointed out that during cheese production and ripening, a decrease in $\mathrm{pH}$ via acidification leads to greater retention and activity of chymosin (Garnot et al., 1987; Belitz et al., 2009). This is another reason that the treatment of 25:75 ( $\mathrm{NaCl}: \mathrm{KCl})$ had the highest WSN/TN percentage. At the end of the storage period, the increase in the WSN/TN percentage (Figure 2) could be also attributed to the proteinases from starter bacteria and $L b$. casei, which are released after the cells have died and lysed (Hannon et al., 2006).
pH, Titratable Acidity, and Concentrations of Lactic and Acetic Acids. The changes in $\mathrm{pH}$, titratable acidity, and redox potential of the trials during the storage period $\left(5^{\circ} \mathrm{C}\right)$ are shown in Figure 2. Table 2 indicates mean $\mathrm{pH}$ drop rate, mean acidity increase rate, and mean redox potential increase rate as well as the final $\mathrm{pH}$ and final titratable acidity in different treatments during the ripening period. As is evident in Figure 2, although the $\mathrm{pH}$ changes did not follow a regular and constant trend, the proportions of $\mathrm{NaCl}: \mathrm{KCl}$ were effective on the $\mathrm{pH}$ decline pattern. This finding was in accordance to the results of Karagö-

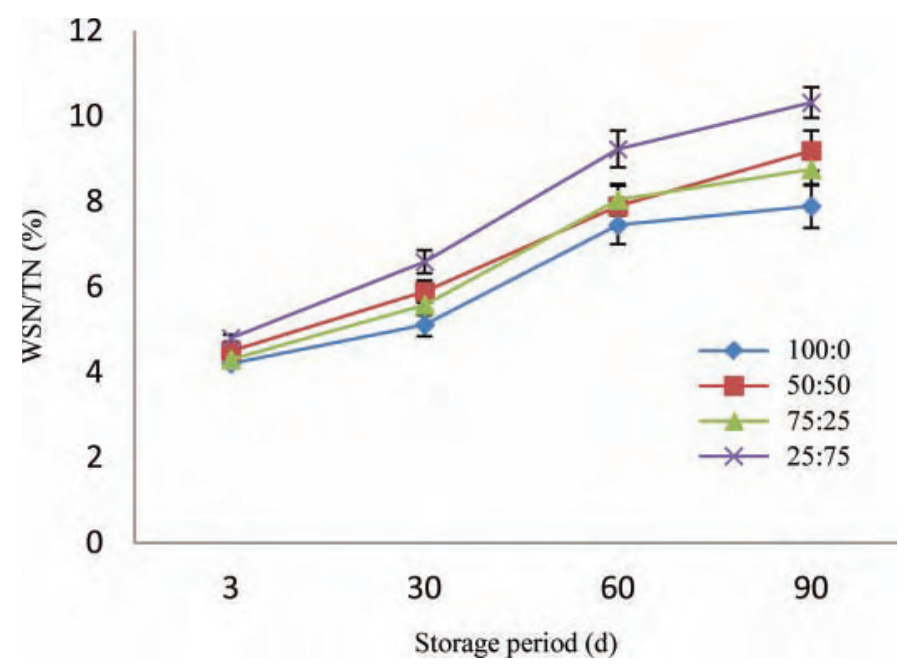

Figure 1. Water-soluble nitrogen/total nitrogen (WSN/TN) in treatments during the ripening period $\left(90 \mathrm{~d}\right.$ at $\left.5^{\circ} \mathrm{C}\right)$. The numbers separated by a colon in the treatments represent the proportions of $\mathrm{NaCl}: \mathrm{KCl}$. The data presented are the means $( \pm \mathrm{SD})$ of 3 replicate trials. Color version available in the online PDF. 
Table 2. Mean $\mathrm{pH}$ drop rate, mean acidity increase rate, and mean redox potential increase rate in different treatments at the end of the storage period $\left(90 \mathrm{~d}\right.$ at $\left.5^{\circ} \mathrm{C}\right)$

\begin{tabular}{|c|c|c|c|c|c|c|c|c|c|}
\hline \multirow[b]{2}{*}{ Parameter } & \multirow{2}{*}{$\begin{array}{l}\text { Treatment } \\
(\mathrm{NaCl}: \mathrm{KCl})\end{array}$} & \multicolumn{7}{|c|}{ Decrease/increase in parameter per time interval (d) } & \multirow{2}{*}{$\begin{array}{c}\begin{array}{c}\text { Final } \\
\text { value }\end{array} \\
90 \mathrm{~d}\end{array}$} \\
\hline & & $3-15$ & $15-30$ & $30-45$ & $45-60$ & $60-75$ & $75-90$ & $3-90$ & \\
\hline \multirow[t]{4}{*}{$\mathrm{pH}$} & 100:0 & +0.01 & -0.01 & +0.01 & 0.00 & -0.00 & 0.00 & 0.00 & 5.01 \\
\hline & $50: 50$ & 0.00 & +0.01 & 0.00 & 0.00 & -0.01 & 0.00 & 0.00 & 4.75 \\
\hline & $75: 25$ & 0.00 & -0.01 & 0.00 & 0.00 & 0.00 & -0.01 & 0.00 & 4.79 \\
\hline & $25: 75$ & 0.00 & -0.01 & 0.00 & 0.00 & 0.00 & 0.01 & 0.00 & 4.60 \\
\hline \multirow[t]{4}{*}{ Titratable acidity $\left({ }^{\circ} \mathrm{D}\right)$} & 100:0 & +1.70 & 0.00 & +2.40 & +0.63 & -0.33 & +6.93 & 1.93 & 221 \\
\hline & $50: 50$ & +3.60 & -1.73 & +0.83 & -0.70 & -1.10 & +18.17 & 2.11 & 249 \\
\hline & $75: 25$ & +2.46 & +1.13 & +0.60 & -0.67 & -0.23 & +15.57 & 2.08 & 237 \\
\hline & $25: 75$ & +4.46 & -1.16 & +0.30 & 0.00 & 0.00 & +17.27 & 2.42 & 276 \\
\hline \multirow[t]{4}{*}{ Redox potential (mV) } & 100:0 & -2.86 & +0.80 & -0.20 & +0.13 & +0.20 & -0.13 & -0.35 & 103 \\
\hline & $50: 50$ & -1.60 & -1.00 & +0.13 & +0.13 & +0.40 & +0.93 & -0.17 & 124 \\
\hline & $75: 25$ & -2.26 & +0.06 & 0.00 & +0.13 & +0.13 & +0.93 & -0.17 & 119 \\
\hline & $25: 75$ & -1.93 & +0.20 & +0.40 & 0.00 & 0.00 & +0.93 & -0.07 & 127 \\
\hline
\end{tabular}
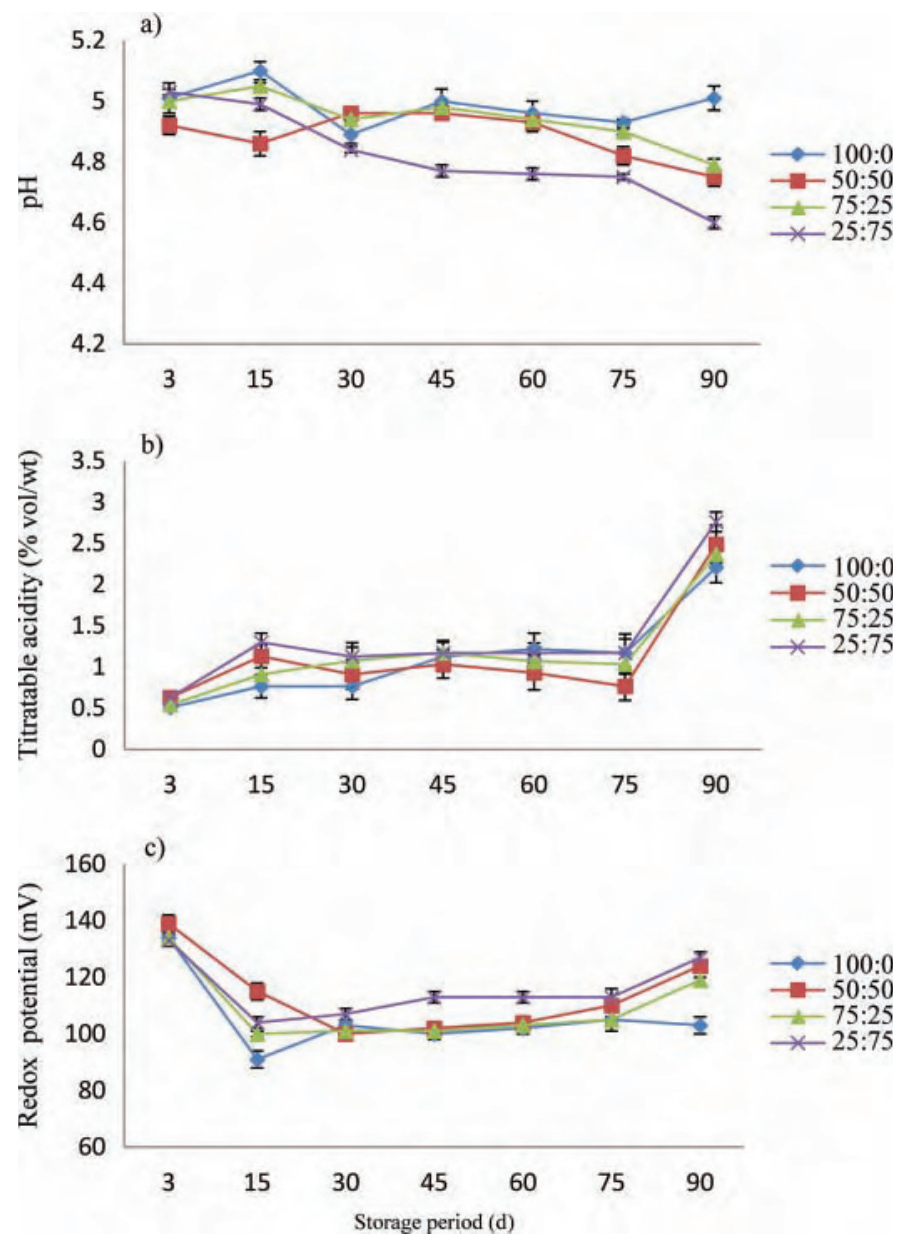

Figure 2. Changes in $\mathrm{pH}(\mathrm{a})$, titratable acidity (b), and redox potential (c) of samples containing different percentages of salt mixtures $(\mathrm{NaCl}: \mathrm{KCl})$ during a $90-\mathrm{d}$ ripening period at $5^{\circ} \mathrm{C}(\mathrm{a}$, b, and c, respectively). The data presented are the means $( \pm \mathrm{SD})$ of 3 replicate trials. Color version available in the online PDF. zlu et al. (2008), in which cheeses with more $\mathrm{KCl}$ content showed lower $\mathrm{pH}$ levels. It could be understood that probiotic and nonprobiotic starter bacteria maintained their activity more adequately in the presence of greater amounts of $\mathrm{KCl}$ compared with $\mathrm{NaCl}$ and led to a higher acidification rate during the ripening period. This fact makes it clear why the treatments of 100:0 and 25:75 ( $\mathrm{NaCl}: \mathrm{KCl})$, respectively, possessed the highest and lowest final $\mathrm{pH}$ levels at the end of storage. The lower inhibition level of $\mathrm{KCl}$ compared with $\mathrm{NaCl}$ could be attributed, on one hand, to the lower osmotic pressure created by the former salt and, on the other hand, to the fact that $\mathrm{K}$ ions seem to be considered as a growth factor for probiotics (Reinheimer et al., 1997; Korbekandi et al., 2011).

According to Figure 2, the $\mathrm{pH}$ decreased continuously (without any turn point) only in the treatment of 25:75 ( $\mathrm{NaCl}: \mathrm{KCl})$ throughout the storage. Comparison of changes in $\mathrm{pH}$ and acidity values during the whole storage time ( 3 to $90 \mathrm{~d}$ ) in Table 2 showed that the highest decrease in $\mathrm{pH}$ as well as the highest increase in acidity was recorded in sample 25:75 ( NaCl:KCl). This indicates that activity and acid production of $L b$. casei and starter bacteria may be higher in the presence of more $\mathrm{KCl}$, as previously noted. This trend can be obviously observed for other samples (also for the final values of $\mathrm{pH}$ and acidity).

According to Figure 2, at the end of the storage time, an increase in $\mathrm{pH}$ occurred for the treatment of 100:0 $(\mathrm{NaCl}: \mathrm{KCl})$ in contrast to the other treatments, which might be attributed to the greater amount of bacterial cell autolysis. This fact has been reported previously by O'Sullivan et al. (2000) for autolysis of lactococcal starter bacteria and Husson-Kao et al. (2000) for autolysis of Strep. thermophilus. Intracellular enzymes, when they are released from the cell following lysis, play a very important role in proteolysis during ripen- 
Table 3. Concentrations (\%) of lactic and acetic acids during the storage period $\left(90 \mathrm{~d}\right.$ at $\left.5^{\circ} \mathrm{C}\right)$

\begin{tabular}{lccccc}
\hline & & \multicolumn{4}{c}{ Storage period $(\mathrm{d})$} \\
\cline { 3 - 5 } Parameter & Treatment & & \multicolumn{4}{c}{} \\
\cline { 3 - 6 } Lactic acid & $100: 0$ & $0.48^{\mathrm{b}}$ & $0.61^{\mathrm{c}}$ & $0.85^{\mathrm{b}}$ & $1.83^{\mathrm{c}}$ \\
& $50: 50$ & $0.54^{\mathrm{a}}$ & $0.85^{\mathrm{b}}$ & $0.74^{\mathrm{c}}$ & $2.11^{\mathrm{b}}$ \\
& $75: 25$ & $0.50^{\mathrm{b}}$ & $0.84^{\mathrm{b}}$ & $0.89^{\mathrm{b}}$ & $1.88^{\mathrm{c}}$ \\
Acetic acid & $25: 75$ & $0.55^{\mathrm{a}}$ & $0.89^{\mathrm{a}}$ & $0.97^{\mathrm{a}}$ & $2.28^{\mathrm{a}}$ \\
& $100: 0$ & $0.03^{\mathrm{b}}$ & $0.09^{\mathrm{d}}$ & $0.20^{\mathrm{b}}$ & $0.26^{\mathrm{b}}$ \\
& $50: 50$ & $0.05^{\mathrm{b}}$ & $0.15^{\mathrm{b}}$ & $0.24^{\mathrm{a}}$ & $0.26^{\mathrm{b}}$ \\
& $75: 25$ & $0.04^{\mathrm{b}}$ & $0.12^{\mathrm{c}}$ & $0.21^{\mathrm{b}}$ & $0.37^{\mathrm{a}}$ \\
& $25: 75$ & $0.08^{\mathrm{a}}$ & $0.20^{\mathrm{a}}$ & $0.25^{\mathrm{a}}$ & $0.36^{\mathrm{a}}$ \\
\hline
\end{tabular}

${ }^{a-d}$ Means within the same column associated with each acid with different superscript letters are significantly different $(P<0.05)$.

ing (Martínez-Cuesta et al., 2001). Also, proteolysis contributes to an increase in $\mathrm{pH}$ by the liberation of intracellular substances with proper buffering capacity (hydrogen ion binding) as well as by the liberation of ammonia from AA produced by proteolysis. These peptidolytic processes, which can enhance the $\mathrm{pH}$ value, occur especially at the end of the storage period (Upadhyay et al., 2004).

It is evident from Figure 2 that the titratable acidity of cheeses at the beginning of storage until d 75 changed slowly. However, this parameter increased dramatically from d 75 onwards. Two reasons are probable for justification of this sharp increase in titratable acidity. First, from d 60 until the end of the ripening period, the viable population of $L b$. casei decreased considerably (see on Viability of $L b$. casei During the Ripening Period and Tables 4 and 5). If it is assumed that the cells of this bacterium have antagonistic and inhibitory effects on nonprobiotic lactic starter bacteria, at the end days of storage, the latter bacteria would have the opportunity to multiply and become markedly more active in acidification. The increase in acidification rate at the final days of ripening or storage has been previously reported by several researchers (Bechaz et al., 1998; Guinee and Fox, 2004). The treatment with $100 \%$ $\mathrm{NaCl}$ had a significantly lower jump in titratable acidity increase compared with other treatments. Second, the starter bacteria could be relatively adapted to the detrimental environmental conditions of the product (such as $\mathrm{pH}$, titratable acidity, and salt), resulting in faster acidification.

Concentrations (\%) of lactic and acetic acids during the ripening period are presented in Table 3. It was observed that the lactic acid concentration in the treatment of 25:75 $(\mathrm{NaCl}: \mathrm{KCl})$ was significantly higher than other treatments during the ripening period, which corresponded with the total titratable acidity. Lactate can be metabolized by lactic acid bacteria, depending on strain, to acetate, ethanol, formate, and $\mathrm{CO}_{2}$ (Fox et al.,
2000). Some strains of $L b$. casei were able to produce acetic acid as their metabolic end products (Shihata and Shah, 2000; Desai et al., 2004). Acetic acid in cheese is typically produced by starter bacteria and normally contributes to its flavor, although high concentrations have been shown to result in off flavors (Fox and Wallace, 1997; Ong et al., 2007). The concentration of this acid in trials was in the range of 0.03 to $0.37 \%$. Trials with the higher content of $\mathrm{KCl}$ had higher amounts of acetic acid. This observation was in agreement with the results of Ayyash and Shah (2010), who illustrated that Halloumi cheeses containing more $\mathrm{KCl}$, overall had a higher acetic acid concentration (Ayyash and Shah, 2010). Considering Table 3, at the end of storage, the greatest concentration of acetic acid was in treatments of 75:25 and 25:75 ( $\mathrm{NaCl}: \mathrm{KCl})$. A direct proportion was evident between the concentration of acetic acid and the viability of $L b$. case $i$ in treatments (Tables 4 and 5). This proportion has been previously reported in several studies in fermented milks (Mortazavian et al., 2010; Shafiee et al., 2010; Heydari et al., 2011).

\section{Viability of Lb. casei During the Ripening Period}

The viability of $L b$. casei during $90 \mathrm{~d}$ of ripening and the VPI are shown in Tables 4 and 5, respectively. Removal of the entire contaminating flora by microfiltration, as has been done in the present study, also offers a means to study precisely how each type of starter and probiotic bacteria added to the retentate will act on different days of cheese ripening. Sodium chloride provides an inhibitory effect upon the survival of probiotic species such as Bifidobacterium lactis and Lactobacillus acidophilus (Gomes et al., 1998). Gobbetti et al. (1998) claimed that the viability of probiotic strains is hindered considerably when the salt level in cheese exceeds the upper limit of $4 \mathrm{~g} / 100 \mathrm{~g}$ of cheese (Gobbetti et al., 1998). Microbial growth inhibition is due to the osmotic effect rather than $\mathrm{NaCl}$ per se, as reflected by 
Table 4. Viability of Lactobacillus casei during the ripening period $\left(90 \mathrm{~d} \text { at } 5^{\circ} \mathrm{C}\right)^{1}$

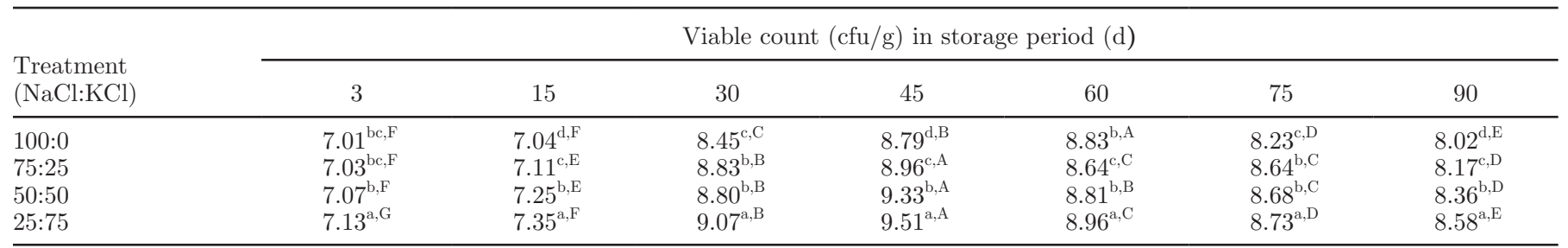

${ }^{\mathrm{a}-\mathrm{d}}$ Means within a column with different superscript lowercase letters are significantly different $(P<0.05)$.

${ }^{\mathrm{A}-\mathrm{G}}$ Means within a row (among different days of the ripening period) with different superscript uppercase letters are significantly different $(P$ $<0.05)$.

${ }^{1}$ The data presented are the mean of 3 replicate trials.

the similar inhibition of growth on substitution of $\mathrm{NaCl}$ by $\mathrm{KCl}$ (Guinee and Fox, 2004).

According to Tables 4 and 5, the maximum viability for all treatments was observed within d 15 to 30 of the ripening period. In this period, the greatest VPI was seen in the treatment of 25:75 ( NaCl:KCl). For the trials of $25: 75,50: 50$, and $75: 25(\mathrm{NaCl}: \mathrm{KCl})$, the greatest viable cell count of $L b$. casei was observed at d 45 of storage, whereas for the rest trial, d 60 was related to the peak of viability. In fact, because $\mathrm{KCl}$ is less inhibitory to probiotic cells than $\mathrm{NaCl}$ (Cruz et al., 2011), the cells proliferate considerably faster, leading to emergence of the peak of viability at an earlier time within the ripening period. In all treatments, an increase in viability of $L b$. casei (growth) occurs until the aforementioned point and then a decrease in viability until the end of storage. The highest and lowest viabilities throughout the $90 \mathrm{~d}$ of ripening period were found for the treatments of 25:75 and 100:0 $(\mathrm{NaCl}: \mathrm{KCl})$, respectively, representing stronger inhibitory effect of $\mathrm{NaCl}$ compared with $\mathrm{KCl}$. The difference in growth rates of $L b$. case $i$ can be attributed to the different osmotic effects of the Na:K mixture. For the trial 25:75 ( $\mathrm{NaCl}: \mathrm{KCl})$, the viability of $L b$. casei was even greater than $9.0 \log \mathrm{cfu} / \mathrm{g}$ at d 30 and 45 . For all treatments, the viable counts were higher than $8.0 \mathrm{log}$ $\mathrm{cfu} / \mathrm{g}$ from d 30 until the end of the ripening time. This reveals that the cheese matrix is a good medium for survival of probiotic bacteria; this has been confirmed in the literature (Karimi et al., 2011). Regarding the inoculated starters, it should be mentioned that among nonprobiotic bacteria, Streptococcus salivarius ssp. thermophilus is considerably less $\mathrm{NaCl}$ tolerant than Lc. lactis ssp. lactis (Ruegg and Blanc, 1981). Also, Lc. lactis ssp. cremoris is more $\mathrm{NaCl}$ sensitive than $L c$. lactis ssp. lactis (Turner and Thomas, 1980).

\section{Syneresis}

Figure 3 shows changes in syneresis of treatments during the ripening period $\left(90 \mathrm{~d}\right.$ at $\left.5^{\circ} \mathrm{C}\right)$. Syneresis increased significantly during storage in all 4 trials. The highest amount of syneresis was observed for the treatment of 25:75 ( NaCl:KCl), whereas the lowest was related to treatments of 75:25 and 100:0 ( $\mathrm{NaCl}: \mathrm{KCl})$. Therefore, addition of $\mathrm{KCl}$ enhanced syneresis. Two mechanisms could be involved in this regard. On one hand, $\mathrm{NaCl}$ increases casein hydration more efficiently than $\mathrm{KCl}$, and a positive relationship exists between the $\mathrm{NaCl}$ content and water-holding capacity of the cheese matrix (Dejmek and Walstra, 2004). On the other hand, cheeses with higher amounts of $\mathrm{KCl}$ compared with $\mathrm{NaCl}$ exhibit a greater decrease in $\mathrm{pH}$ and acidity increase during ripening time (see Chemical and Biochemical Characteristics). As a rule, in high-pH cheeses, absorption of water is very high but is limited at low pH (Fox et al., 2000). This occurs because the rate of rearrangements of protein-protein bonds in the casein gels, especially the network of paracasein micelles during their formation, increases as $\mathrm{pH}$ decreases (Watkinson et al., 2001). As the concentration of hydrogen ions increases during acidification, the repulsive forces decrease, and the casein micelles begin to aggregate. It should be pointed out at the end that the significant increase in syneresis during storage influences the increase in hardness (Souza and Saad, 2008) and adhesiveness (Pastorino et al., 2003) and affects the texture for sensory properties. Also, syneresis regulates the growth of bacteria and the activity of the enzymes in the cheese; consequently, it strongly influences the rate and pattern of ripening and the quality of the finished cheese (Fox and McSweeney, 2004).

\section{Sensory Characteristics}

Mean scores of the sensory panels for cheeses inoculated with $L b$. casei made by partial replacement of $\mathrm{NaCl}$ with $\mathrm{KCl}$ are listed in Table 6 . Treatments of 100:0 and 75:25 $(\mathrm{NaCl}: \mathrm{KCl})$ received higher scores for flavor and general acceptance within the entire storage period. It can be understood from Table 6 that a negative significant correlation existed between the flavor 


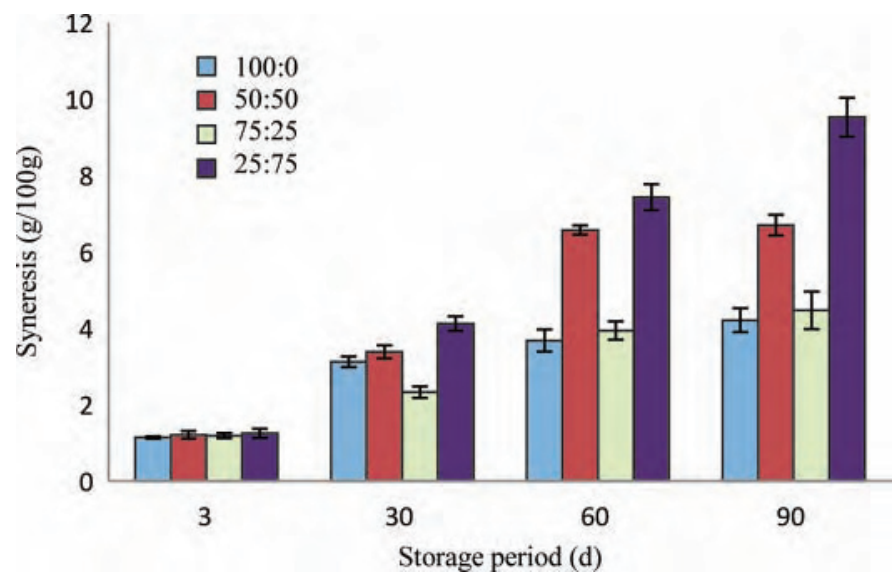

Figure 3. Syneresis percentage in treatments (proportion of $\mathrm{NaCl}: \mathrm{KCl})$ during the ripening period $\left(90 \mathrm{~d}\right.$ at $\left.5^{\circ} \mathrm{C}\right)$. The data presented are the means $( \pm \mathrm{SD})$ of 3 replicate trials. Color version available in the online PDF.

and general acceptance of the samples and higher $\mathrm{NaCl}$ substitution rate by $\mathrm{KCl}(50: 50$ and $25: 75 \mathrm{NaCl}: \mathrm{KCl})$. Texture scores of samples 100:0 and 75:25 ( NaCl:KCl) were higher than those of samples 50:50 and 25:75 (NaCl:KCl). No significant difference $(P>0.05)$ occurred in the appearance of all samples on each day at d 3 and 90, whereas sample 75:25 ( $\mathrm{NaCl}: \mathrm{KCl})$ had a higher score at 30 and $60 \mathrm{~d}$ of storage.

The most common concern in replacement of a portion of the $\mathrm{NaCl}$ with $\mathrm{KCl}$ is the tendency to cause bitter or other taste defects such as a metallic taste. Bitter flavor (not due to abnormal proteolysis) is detectable in cheese containing $>1 \%$ (wt/wt) $\mathrm{KCl}$ (Guinee and Fox, 2004). Bitterness emerged due to the effect of $\mathrm{KCl}$ itself, or due to its effect on enhancing proteolysis and causing a higher WSN/TN percentage (Guinee and Fox, 2004; Bintsis, 2006). The effectiveness of $\mathrm{NaCl}$ in preventing bitterness is very likely due to the strong inhibition of $\beta$-CN hydrolysis by $\mathrm{NaCl}$ (Kelly et al., 1996; Mistry and Kasperson, 1998).

According to the general acceptance scores in Table 6 , cheese with $\mathrm{NaCl}$ alone and with only $25 \%$ replacement by $\mathrm{KCl}$ had the highest sensory acceptability. Therefore, it could be concluded that partial replacement of $\mathrm{NaCl}$ by $\mathrm{KCl}$ that did not exceed $25 \%$ did not significantly affect the flavor and total acceptance of UF Feta cheese. Other studies confirm this idea in different cheeses. Katsiari et al. (1997) reported that Feta cheese salted with a $3: 1 \mathrm{NaCl}: \mathrm{KCl}$ mixture received a higher flavor score than cheese salted with a 1:1 NaCl:KCl mixture, and there was a slightly bittermetallic aftertaste, typical of $\mathrm{KCl}$ in cheese with a 1:1 $\mathrm{NaCl}: \mathrm{KCl}$ mixture (Katsiari et al., 1997). A similar trend has been observed in Cheddar cheese (Reddy and Marth, 1994) and in Domiati cheese (Ramadan, 1995).

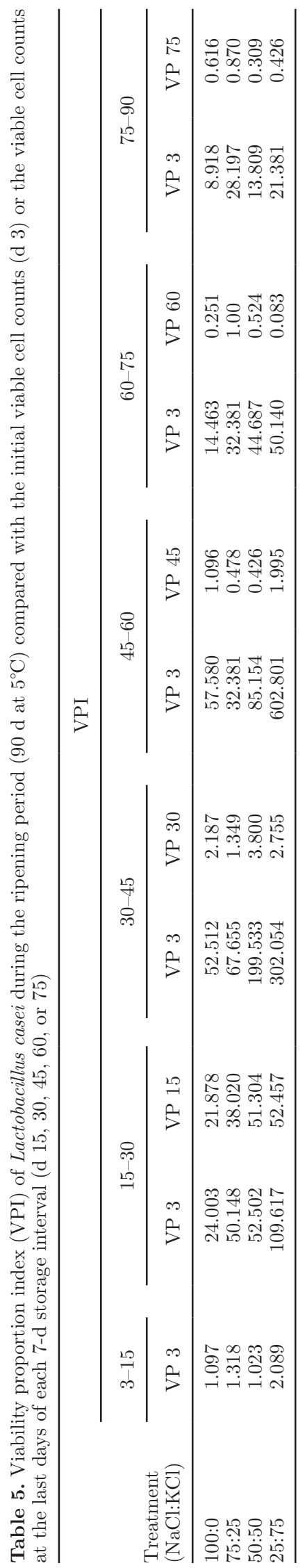

Journal of Dairy Science Vol. 95 No. 8, 2012 
Table 6. Sensory attributes of treatments during the ripening period $\left(90 \mathrm{~d} \text { at } 5^{\circ} \mathrm{C}\right)^{1}$

\begin{tabular}{lccccc}
\hline & & \multicolumn{5}{c}{ Storage period $(\mathrm{d})$} \\
\cline { 3 - 6 } Attribute & $\begin{array}{c}\text { Treatment } \\
\text { (NaCl:KCl) }\end{array}$ & 3 & 30 & 60 & 90 \\
\hline Flavor & $100: 0$ & $4.3^{\mathrm{a}, \mathrm{C}}$ & $4.4^{\mathrm{a}, \mathrm{B}}$ & $4.5^{\mathrm{a}, \mathrm{A}}$ & $3.5^{\mathrm{b}, \mathrm{D}}$ \\
& $50: 50$ & $3.1^{\mathrm{c}, \mathrm{C}}$ & $3.4^{\mathrm{c}, \mathrm{B}}$ & $3.7^{\mathrm{b}, \mathrm{A}}$ & $3.0^{\mathrm{c}, \mathrm{D}}$ \\
& $75: 25$ & $4.0^{\mathrm{b}, \mathrm{C}}$ & $4.1^{\mathrm{b}, \mathrm{B}}$ & $4.5^{\mathrm{a}, \mathrm{A}}$ & $3.7^{\mathrm{a}, \mathrm{D}}$ \\
Texture & $25: 75$ & $2.4^{\mathrm{d}, \mathrm{A}}$ & $2.2^{\mathrm{d}, \mathrm{B}}$ & $2.1^{\mathrm{c}, \mathrm{C}}$ & $1.7^{\mathrm{d}, \mathrm{D}}$ \\
& $100: 0$ & $4.0^{\mathrm{a}, \mathrm{B}}$ & $4.3^{\mathrm{a}, \mathrm{A}}$ & $4.3^{\mathrm{b}, \mathrm{A}}$ & $4.0^{\mathrm{a}, \mathrm{B}}$ \\
& $50: 50$ & $3.5^{\mathrm{b}, \mathrm{A}}$ & $3.5^{\mathrm{c}, \mathrm{A}}$ & $3.5^{\mathrm{c}, \mathrm{A}}$ & $3.2^{\mathrm{b}, \mathrm{B}}$ \\
Appearance & $75: 25$ & $4.0^{\mathrm{a}, \mathrm{C}}$ & $4.4^{\mathrm{a}, \mathrm{B}}$ & $4.5^{\mathrm{a}, \mathrm{A}}$ & $4.0^{\mathrm{a}, \mathrm{C}}$ \\
& $25: 75$ & $4.0^{\mathrm{a}, \mathrm{A}}$ & $4.0^{\mathrm{b}, \mathrm{A}}$ & $3.5^{\mathrm{c}, \mathrm{B}}$ & $3.0^{\mathrm{c}, \mathrm{C}}$ \\
General acceptance & $100: 0$ & $4.0^{\mathrm{a}, \mathrm{B}}$ & $4.1^{\mathrm{b}, \mathrm{A}}$ & $4.0^{\mathrm{b}, \mathrm{B}}$ & $3.5^{\mathrm{a}, \mathrm{C}}$ \\
& $50: 50$ & $4.0^{\mathrm{b}, \mathrm{B}}$ & $4.1^{\mathrm{b}, \mathrm{A}}$ & $4.0^{\mathrm{b}, \mathrm{B}}$ & $3.5^{\mathrm{a}, \mathrm{C}}$ \\
& $75: 25$ & $4.0^{\mathrm{b}, \mathrm{B}}$ & $4.2^{\mathrm{a}, \mathrm{A}}$ & $4.2^{\mathrm{a}, \mathrm{A}}$ & $3.5^{\mathrm{a}, \mathrm{C}}$ \\
& $25: 75$ & $4.0^{\mathrm{b}, \mathrm{B}}$ & $4.1^{\mathrm{b}, \mathrm{A}}$ & $4.0^{\mathrm{b}, \mathrm{B}}$ & $3.5^{\mathrm{a}, \mathrm{C}}$ \\
& $100: 0$ & $4.2^{\mathrm{a}, \mathrm{B}}$ & $4.4^{\mathrm{a}, \mathrm{A}}$ & $4.4^{\mathrm{b}, \mathrm{A}}$ & $3.7^{\mathrm{b}, \mathrm{C}}$ \\
& $50: 50$ & $3.4^{\mathrm{c}, \mathrm{B}}$ & $3.4^{\mathrm{c}, \mathrm{B}}$ & $3.5^{\mathrm{c}, \mathrm{A}}$ & $3.0^{\mathrm{c}, \mathrm{C}}$ \\
& $75: 25$ & $4.1^{\mathrm{b}, \mathrm{C}}$ & $4.2^{\mathrm{b}, \mathrm{B}}$ & $4.5^{\mathrm{a}, \mathrm{A}}$ & $3.9^{\mathrm{a}, \mathrm{D}}$ \\
& $25: 75$ & $2.2^{\mathrm{d}, \mathrm{A}}$ & $2.1^{\mathrm{d}, \mathrm{B}}$ & $2.0^{\mathrm{d}, \mathrm{C}}$ & $1.5^{\mathrm{d}, \mathrm{D}}$ \\
\hline
\end{tabular}

\footnotetext{
${ }^{\mathrm{a}-\mathrm{d}}$ Means within each column (associated with each sensory parameter) with different superscript lowercase letters are significantly different $(P<0.05)$.

${ }^{\mathrm{A}-\mathrm{D}}$ Means within a row (among different days of the ripening period) with different superscript uppercase letters are significantly different $(P<0.05)$.

${ }^{1}$ The data presented are the mean of 3 replicate trials.
}

Lindsay et al. (1985) found that the use of substitutes, (i.e., $\mathrm{KC} 1$ or $\mathrm{KC} 1: \mathrm{NaC} 1)$ to reduce the level of sodium by $50 \%$ gave a significant reduction in quality (Lindsay et al., 1985). Aly (1995) concluded that cheeses containing $0.5 \% \mathrm{KC} 1+1.5 \% \mathrm{NaCl}$ had similar flavor and body and texture properties as those containing $\mathrm{NaCl}$ alone (Aly, 1995). Also, Demott et al. (1986) evaluated consumer reactions to low-sodium cottage cheese salted with various mixtures of $\mathrm{KCl}$ and $\mathrm{NaCl}$ and found that the sodium level could be decreased by $50 \%$ without affecting grading scores (Demott et al., 1986).

In the trial 25:75 ( $\mathrm{NaCl}: \mathrm{KCl})$, an appreciable bitter taste was observed during the whole storage period. However, the trial $75: 25$ ( $\mathrm{NaCl}: \mathrm{KCl})$ was acceptable and did not exhibit a bitter-metallic taste, not only because of the direct effect of $\mathrm{KCl}$ on taste, but also probably due to the masking effect of $\mathrm{NaCl}$ on bitterness (Bintsis, 2006). It has been reported that whenever the starter bacteria or other factors cause formation of bitter peptides, the $\mathrm{KCl}$ might not inhibit or mask development of bitterness to the same extent as $\mathrm{NaCl}$ (Laborda and Rubiolo, 1999).

Regarding the changes of sensory attributes of the samples during the storage period, it is necessary to mention that flavor scores of samples 100:0, 50:50, and 75:25 increased until $\mathrm{d} 60$ and then decreased. The same trend was seen for general acceptance. This means that proteolysis during ripening might ameliorate these properties, but after that time these 2 quality parameters decrease. On the other hand, in sample 25:75 ( $\mathrm{NaCl}: \mathrm{KCl})$, flavor and general acceptance deteriorated with an increase in the storage period. This indicates that the higher level of proteolysis in this sample may have been deleterious for acceptable quality of cheese.

In some studies, Lb. casei incorporated in Cheddar cheese (Broome et al., 1990; Trépanier et al., 1991a,b; Muir et al., 1996) showed enhanced flavor development and intensity. However, in other types of cheese such as Emmental (Rychlik et al., 1997) and Mozzarella (Merrill et al., 1996), no significant effect on flavor was found. As previously mentioned, Lb. case $i$ is known to produce acetic acid (see Chemical and Biochemical Characteristics). Acetic acid production in the probiotic cheeses are reflected in the sensory characteristics. In small amounts, acetic acid exerts a positive influence on the aroma of probiotic cheeses. However, excessive concentrations are undesirable, causing off flavors (Grattepanche et al., 2008). This acid cause vinegary taste, that is more difficult to detect in the presence of other components such as fat, protein, acid, and salt (Ong et al., 2007). In the present study, the flavor of the cheeses was still within the acceptable range and was not affected by acetic acid content. According to Table 3, the amount of acetic acid in all treatments did not exceed $0.37 \%$.

\section{CONCLUSIONS}

A higher content of $\mathrm{KCl}$ in cheese resulted in higher viable counts of $L b$. casei until $45 \mathrm{~d}$ of storage. The viable cell population of $L b$. casei in all samples was higher than $8 \log \mathrm{cfu} / \mathrm{g}$ at the end of the $90-\mathrm{d}$ stor- 
age period. Sample 75:25 ( $\mathrm{NaCl}: \mathrm{KCl})$ had the highest survivability (8.58 log $\mathrm{cfu} / \mathrm{g}$ ) compared with the other samples. After $30 \mathrm{~d}$ of storage, $\mathrm{pH}$ values decreased with the increase in $\mathrm{KCl}$ content. Cheeses salted with the proportion of 100:0 and 75:25 ( NaCl:KCl) were most preferred by the panelists with respect to flavor and general acceptance. Also, with an increase in the storage time, flavor and general acceptance increased up to $60 \mathrm{~d}$ in 100:0, 50:50, and 75:25 ( $\mathrm{NaCl}: \mathrm{KCl})$ samples. Cheese salted with large amounts of $\mathrm{KCl}$ such as $75 \%$ or $50 \%$ had excessive syneresis after $60 \mathrm{~d}$ of storage. Overall, low-sodium probiotic UF Feta cheese could be manufactured with the mixture of $75 \% \mathrm{NaCl}$ $+25 \% \mathrm{KCl}$ without negative effects on viability of $L b$. casei and sensory properties of cheese. Incorporation of other probiotic bacteria coincidently with the presence of a $\mathrm{NaCl}: \mathrm{KCl}$ mixture in the aforementioned cheese is recommended to be investigated.

\section{ACKNOWLEDGMENTS}

This article is related to a student thesis from Shahid Beheshti University of Medical Sciences (Tehran, Iran). The samples were produced in the PAK Dairy Complex (Pakara, Sanandaj, Iran). The authors thank S. Sohrabvandi (Shahid Beheshti University of Medical Sciences, Tehran, Iran) for assistance with statistical design.

\section{REFERENCES}

Agarwal, S., D. McCoy, W. Graves, P. D. Gerard, and S. Clark. 2011. Sodium content in retail Cheddar, Mozzarella, and process cheeses varies considerably in the United States. J. Dairy Sci. 94:16051615.

Albenzio, M., A. Santillo, M. Caroprese, R. Marino, A. Trani, and M. Faccia. 2010. Biochemical patterns in ovine cheese: Influence of probiotic strains. J. Dairy Sci. 93:3487-3496.

Alizadeh, M., M. Hamedi, and A. Khosroshahi. 2006. Modeling of proteolysis and lipolysis in Iranian white brine cheese. Food Chem. $97: 294-301$.

Aly, M. E. 1995. An attempt for producing low-sodium Feta-type cheese. Food Chem. 52:295-299.

AOAC (Association of Official Analytical Chemists). 1990. AOAC Official Methods of Analysis. Vol. 2. 15th ed. Association of Official Analytical Chemists, Arlington, VA.

Ayyash, M. M., and N. P. Shah. 2010. Effect of partial substitution of $\mathrm{NaCl}$ with $\mathrm{KCl}$ on Halloumi cheese during storage: Chemical composition, lactic bacterial count, and organic acids production. J. Food Sci. 75:C525-C529.

Ayyash, M. M., F. Sherkat, P. Francis, R. P. W. Williams, and N. P. Shah. 2011. The effect of sodium chloride substitution with potassium chloride on texture profile and microstructure of Halloumi cheese. J. Dairy Sci. 94:37-42.

Bechaz, S. R., M. W. Hickey, G. K. Y. Limsowtin, and A. G. Morgan. 1998. Low-salt cheddar: A microbial investigation. Aust. J. Dairy Technol. 53:128.

Belitz, H.-D., W. Grosch, and P. Schieberle. 2009. Amino Acids, Peptides, Proteins. Pages 8-89 in Food Chemistry. 4th ed. Springer, Heidelberg, Germany.
Bergamini, C. V., E. R. Hynes, M. C. Candioti, and C. A. Zalazar. 2009. Multivariate analysis of proteolysis patterns differentiated the impact of six strains of probiotic bacteria on a semi-hard cheese. J. Dairy Sci. 92:2455-2467.

Bergamini, C. V., E. R. Hynes, A. Quiberoni, V. B. Suárez, and C. A. Zalazar. 2005. Probiotic bacteria as adjunct starters: Influence of the addition methodology on their survival in a semi-hard Argentinean cheese. Food Res. Int. 38:597-604.

Bintsis, T. 2006. Quality of the brine. Pages 264-301 in Brined Cheeses. A. Y. Tamime, ed. Blackwell, Oxford, UK.

Boylston, T. D., C. G. Vinderola, H. B. Ghoddusi, and J. A. Reinheimer. 2004. Incorporation of bifidobacteria into cheeses: Challenges and rewards. Int. Dairy J. 14:375-387.

Broome, M. C., D. A. Krause, and M. W. Hickey. 1990. The use of nonstarter lactobacilli in Cheddar cheese manufacture. Aust. J. Dairy Technol. 45:67-73.

BSI (British Standards Institution). 1995. Gerber method for the determination of fat in milk and milk products. British Standard 696. British Standards Institution, London, UK.

Buriti, F. C. A., J. S. da Rocha, E. G. Assis, and S. M. I. Saad. 2005. Probiotic potential of Minas fresh cheese prepared with the addition of Lactobacillus paracasei. Lebensm. Wiss. Technol. 38:173180.

Champagne, C. P., and R. A. Rastall. 2009. Some technological challenges in the addition of probiotic bacteria to foods. Pages 763-806 in Prebiotics and Probiotics Science and Technology. D. Charalampopoulos and R. A. Rastall, ed. Springer, New York, NY.

Cheryan, M. 1998. Ultrafiltration and Microfiltration Handbook. Technomic Publishing, Lancaster, PA.

Cheryan, M., and J. R. Alvarez. 1995. Food and beverage industry applications. Pages 415-465 in Membrane Separations Technology: Principles and Applications. R. D. Noble and S. A. Stern, ed. Elsevier Science, New York, NY.

Cogan, T. M., T. P. Beresford, J. Steele, J. Broadbent, N. P. Shah, and Z. Ustunol. 2007. Invited review: Advances in starter cultures and cultured foods. J. Dairy Sci. 90:4005-4021.

Corbo, M. R., M. Albenzio, M. De Angelis, A. Sevi, and M. Gobbetti. 2001. Microbiological and biochemical properties of Canestrato Pugliese hard cheese supplemented with bifidobacteria. J. Dairy Sci. 84:551-561.

Cruz, A. G., J. A. F. Faria, M. A. R. Pollonio, H. M. A. Bolini, R. M. S. Celeghini, D. Granato, and N. P. Shah. 2011. Cheeses with reduced sodium content: Effects on functionality, public health benefits and sensory properties. Trends Food Sci. Technol. 22:276-291.

De Vuyst, L. 2000. Technology aspects related to the application of functional starter cultures. Food Technol. Biotechnol. 38:105-112.

Dejmek, P., and P. Walstra. 2004. The syneresis of rennet-coagulated curd. Pages 71-103 in Cheese Chemistry, Physics and Microbiology. Vol. 1. P. F. Fox, P. L. H. McSweeney, T. M. Cogan, and T. P. Guinee, ed. Elsevier Academic Press, London, UK.

Demott, B. J., J. P. Hitchcock, and P. N. Davidson. 1986. Use of sodium substitute in cottage cheese and butter milk. J. Food Prot. 49:117-120.

Desai, A. R., I. B. Powell, and N. P. Shah. 2004. Survival and activity of probiotic lactobacilli in skim milk containing prebiotics. J. Food Sci. 69:FMS57-FMS60.

Drake, S. L., K. Lopetcharat, and M. A. Drake. 2011. Salty taste in dairy foods: Can we reduce the salt? J. Dairy Sci. 94:636-645.

El-Gazzar, F. E., and E. H. Marth. 1991. Ultrafiltration and reverse osmosis in dairy technology: A review. J. Food Prot. 54:801-809.

FAO/WHO (Food and Agriculture Organization of the United Nations/World Health Organization). 2001. Health and nutritional properties of probiotics in food including powder milk with live lactic acid bacteria. Report of a joint FAO/WHO expert consultation. FAO/WHO, Córdoba, Argentina.

Farkye, N., and P. F. Fox. 1992. Contribution of plasmin to Cheddar cheese ripening: Effect of added plasmin. J. Dairy Res. 59:209216 
Fox, P. F., T. P. Guinee, T. M. Cogan, and P. L. H. McSweeney. 2000 Fundamentals of Cheese Science. Aspen Publishers Inc., Gaithersburg, MD.

Fox, P. F., and P. L. H. McSweeney. 1996. Proteolysis in cheese during ripening. Food Rev. Int. 12:457-509.

Fox, P. F., and P. L. H. McSweeney. 2004. Cheese: An Overview. Vol 1. 3rd ed. Cheese: Chemistry, Physics and Microbiology. Elsevier Academic Press, London, UK.

Fox, P. F., and J. M. Wallace. 1997. Formation of flavor compounds in cheese. Adv. Appl. Microbiol. 45:17-85.

Fritzen-Freire, C. B., C. M. O. Müller, J. B. Laurindo, R. D. de M. C. Amboni, and E. S. Prudêncio. 2010a. The effect of direct acidification on the microbiological, physicochemical and sensory properties of probiotic Minas Frescal cheese. Int. J. Dairy Technol. 63:561-568.

Fritzen-Freire, C. B., C. M. O. Müller, J. B. Laurindo, and E. S. Prudêncio. 2010b. The influence of Bifidobacterium Bb-12 and lactic acid incorporation on the properties of Minas Frescal cheese. J. Food Eng. 96:621-627.

Garnot, P., D. Molle, and M. Piot. 1987. Influence of pH, type of enzyme and ultrafiltration on the retention of milk clotting enzymes in Camembert cheese. J. Dairy Res. 54:315-320.

Ghoddusi, H. B., and R. K. Robinson. 1996. The test of time. Dairy Indust. Int. 61:25-28.

Gobbetti, M., A. Corsetti, E. Smacchi, A. Zocchetti, and M. De Angelis. 1998. Production of Crescenza cheese by incorporation of bifidobacteria. J. Dairy Sci. 81:37-47.

Gobbetti, M., R. Lanciotti, M. de Angelis, M. R. Corbo, R. Massini, and R. E. Fox. 1999. Study of the effects of temperature, $\mathrm{pH}$ and $\mathrm{NaC} 1$ on the peptidase activities of non-starter lactic acid bacteria (NSLAB) by quadratic response surface methodology. Int. Dairy J. $9: 865-875$.

Gomes, A. A., S. P. Braga, A. G. Cruz, R. S. Cadena, P. C. B. Lollo, C. Carvalho, J. Amaya-Farfán, J. A. F. Faria, and H. M. A. Bolini. 2011a. Effect of the inoculation level of Lactobacillus acidophilus in probiotic cheese on the physicochemical features and sensory performance towards commercial cheeses. J. Dairy Sci. 94:47774786 .

Gomes, A. M. P., and F. X. Malcata. 1998. Development of probiotic cheese manufactured from goat milk: Response surface analysis via technological manipulation. J. Dairy Sci. 81:1492-1507.

Gomes, A. M. P., M. M. Vieira, and F. X. Malcata. 1998. Survival of probiotic microbial strains in a cheese matrix during ripening: Simulation of rates of salt diffusion and microorganism survival. J. Food Eng. 36:281-301.

Gomes, A. P., A. G. Cruz, R. S. Cadena, R. M. S. Celeghini, J. A. F. Faria, H. M. A. Bolini, M. A. R. Pollonio, and D. Granato. 2011b. Manufacture of low-sodium Minas fresh cheese: Effect of the partial replacement of sodium chloride with potassium chloride. J. Dairy Sci. 94:2701-2706.

Gomes da Cruz, A., F. C. Alonso Buriti, C. H. Batista de Souza, J. A. Fonseca Faria, and S. M. Isay Saad. 2009. Probiotic cheese: Health benefits, technological and stability aspects. Trends Food Sci. Technol. 20:344-354

Goulding, A. 1997. Sodium and calcium metabolism. Pages 33-36 in IDF Bulletin No. 322. International Dairy Federation, Brussels, Belgium.

Granato, D., G. F. Branco, A. G. Cruz, J. de Assis Fonseca Faria, and N. P. Shah. 2010. Probiotic dairy products as functional foods. Comp. Rev. Food Sci. Food Safety 9:455-470.

Grattepanche, F., S. Miescher-Schwenninger, L. Meile, and C. Lacroix 2008. Recent developments in cheese cultures with protective and probiotic functionalities. Dairy Sci. Technol. 88:421-444.

Guinee, T. P. 2004. Salting and the role of salt in cheese. Int. J. Dairy Technol. 57:99-109.

Guinee, T. P., and P. F. Fox. 2004. Salt in cheese: Physical, chemical and biological aspects. Pages 207-259 in Cheese Chemistry, Physics and Microbiology. Vol. 1. 3rd ed. P. F. Fox, P. L. H. McSweeney, T. M. Cogan, and T. P. Guinee, ed. Elsevier Academic Press, London, UK.
Güven, M., and O. B. Karaca. 2001. Proteolysis levels of white cheeses salted and ripened in brines prepared from various salts. Int. J. Dairy Technol. 54:29-33.

Hannon, J. A., S.-M. Deutsch, M.-N. Madec, J.-Y. Gassi, M.-P Chapot-Chartier, and S. Lortal. 2006. Lysis of starters in UF cheeses: Behaviour of mesophilic lactococci and thermophilic lactobacilli. Int. Dairy J. 16:324-334.

Heydari, S., A. M. Mortazavian, M. R. Ehsani, M. A. Mohammadifar, H. Ezzatpanah, and S. Sohrabvandi. 2011. Biochemical, microbiological and sensory characteristics of probiotic yogurt containing various prebiotic or fiber compounds. Ital. J. Food Sci. 23:153163.

Husson-Kao, C.. J. Mengaud, B. Cesselin, D. van Sinderen, L. Benbadis, and M. P. Chapot-Chartier. 2000. The Streptococcus thermophilus autolytic phenotype results from a leaky prophage. Appl. Environ. Microbiol. 66:558-565.

Ibrahim, F., S. Ruvio, L. Granlund, S. Salminen, M. Viitanen, and A C. Ouwehand. 2010. Probiotics and immunosenescence: Cheese as a carrier. FEMS Immunol. Med. Microbiol. 59:53-59.

IDF (International Dairy Federation). 1993. Determination of nitrogen content. Standard 20B. International Dairy Federation, Brussels, Belgium.

Ishibashi, N., and S. Shimamura. 1993. Bifidobacteria: Research and development in Japan. Food Technol. 47:126-136.

ISIRI (Institute of Standards and Industrial Research of Iran). 2001 Iran national standard for cheese-Determination of titrable acidity - Test method no. 2852. Accessed Jun. 7, 2012. http://std.isiri org/std/2852.pdf. [In Persian].

ISIRI (Institute of Standards and Industrial Research of Iran). 2008 Iran national standard for probiotic Doogh; No. 11324. Accessed Jun. 7, 2012. http://std.isiri.org/std/11324.pdf. [In Persian].

ISO (International Organization for Standardization). 2009. Milk and milk products - Sensory analysis - Part 2: Recommended methods for sensory evaluation. ISO 22935-2:2009 (IDF 99-2:2009). ISO, Geneva, Switzerland.

Johnson, M. E., R. Kapoor, D. J. McMahon, D. R. McCoy, and R. G. Narasimmon. 2009. Reduction of sodium and fat levels in natural and processed cheeses: Scientific and technological aspects. Comp. Rev. Food Sci. Food Safety 8:252-268.

Karagözlu, C., O. Kinik, and N. Akbulut. 2008. Effects of fully and partial substitution of $\mathrm{NaCl}$ by $\mathrm{KCl}$ on physico-chemical and sensory properties of white pickled cheese. Int. J. Food Sci. Nutr. 59:181-191.

Karami, M., M. R. Ehsani, S. M. Mousavi, K. Rezaei, and M. Safari 2009a. Changes in the rheological properties of Iranian UF-Feta cheese during ripening. Food Chem. 112:539-544.

Karami, M., M. R. Ehsani, S. M. Mousavi, K. Rezaei, and M. Safari 2009b. Microstructural properties of fat during the accelerated ripening of ultrafiltered-Feta cheese. Food Chem. 113:424-434.

Karimi, R., A. M. Mortazavian, and A. Amiri-Rigi. 2012. Selective enumeration of probiotic microorganisms in cheese. Food Microbiol. 29:1-9. http://dx.doi.org/10.1016/j.fm.2011.08.008.

Karimi, R., A. M. Mortazavian, and A. Gomes Da Cruz. 2011. Viability of probiotic microorganisms in cheese during production and storage: A review. Dairy Sci. Technol. 91:283-308.

Kasımoğlu, A., M. Göncüoğlu, and S. Akgün. 2004. Probiotic white cheese with Lactobacillus acidophilus. Int. Dairy J. 14:1067-1073.

Katsiari, M. C., E. Alichanidis, L. P. Voutsinas, and I. G. Roussis, 2000a. Proteolysis in reduced sodium Feta cheese made by partial substitution of $\mathrm{NaCl}$ by $\mathrm{KCl}$. Int. Dairy J. 10:635-646.

Katsiari, M. C., E. Alichanidis, L. P. Voutsinas, and I. G. Roussis. 2001. Proteolysis in reduced sodium Kefalograviera cheese made by partial replacement of $\mathrm{NaCl}$ with $\mathrm{KCl}$. Food Chem. 73:31-43.

Katsiari, M. C., L. P. Voutsinas, E. Alichanidis, and I. G. Roussis 1997. Reduction of sodium content in Feta cheese by partial substitution of $\mathrm{NaCl}$ by KCl. Int. Dairy J. 7:465-472.

Katsiari, M. C., L. P. Voutsinas, E. Alichanidis, and I. G. Roussis 2000b. Lipolysis in reduced sodium Feta cheese made by partial substitution of $\mathrm{NaCl}$ by $\mathrm{KCl}$. Int. Dairy J. 10:369-373. 
Kelly, M., P. F. Fox, and P. L. H. McSweeney. 1996. Effect of saltin-moisture on proteolysis in Cheddar-type cheese. Milchwissenschaft 51:498-501.

Korbekandi, H., A. M. Mortazavian, and S. Iravani. 2011. Technology and stability of probiotic in fermented milks. Pages 131-169 in Probiotic and Prebiotic Foods: Technology, Stability and Benefits to the Human Health. N. P. Shah, ed. Nova Science Publishers, New York, NY.

Kosikowski, F. V., and V. V. Mistry. 1997. Ultrafiltration in cheese making. Pages 403-420 in Cheese and Fermented Milk Foods. Vol. 1: Origins and Principles F. V. Kosikowski and V. V. Mistry, ed. F. V. Kosikowski LLC, Westport, CT.

Laborda, M. A., and A. C. Rubiolo. 1999. Proteolysis of Fynbo cheese salted with $\mathrm{NaCl} / \mathrm{KCl}$ and ripened at two temperatures. J. Food Sci. $64: 33-36$

Lee, K. Y., K. Nomoto, S. Salminen, and S. L. Gorbach. 1999. Handbook of Probiotics. John Wiley \& Sons, New York, NY.

Lindsay, R. C., C. Karahadian, and C. H. Amudson. 1985. Low sodium cheese: An overview and properties of Cheddar cheese made with UF and RO retentate supplemented milk. Pages 55-76 in Proc. IDF Seminar, Atlanta, GA.

Madureira, A. R., M. Amorim, A. M. Gomes, M. E. Pintado, and F. X. Malcata. 2011a. Protective effect of whey cheese matrix on probiotic strains exposed to simulated gastrointestinal conditions. Food Res. Int. 44:465-470.

Madureira, A. R., T. Brandão, A. M. Gomes, M. E. Pintado, and F. X. Malcata. 2011b. Technological optimization of manufacture of probiotic whey cheese matrices. J. Food Sci. 76:E203-E211.

Martínez-Cuesta, M. C., P. F. de Palencia, T. Requena, and C. Peláez. 2001. Enzymatic ability of Lactobacillus casei ssp. casei IFPL731 for flavour development in cheese. Int. Dairy J. 11:577-585.

McSweeney, P. L. H. 2004. Biochemistry of cheese ripening: Introduction and overview. Pages 347-360 in Cheese Chemistry, Physics and Microbiology. Vol. 1. 3rd ed. P. F. Fox, P. L. H. McSweeney, T. M. Cogan, and T. P. Guinee, ed. Elsevier Academic Press, London, UK.

Merrill, R. K., C. J. Oberg, W. R. McManus, M. Kalab, and D. J. McMahon. 1996. Microstructure and physical properties of a reduced fat Mozzarella cheese made using Lactobacillus casei ssp. casei adjunct culture. Lebensm. Wiss. Technol. 29:721-728.

Mistry, V. V., and K. M. Kasperson. 1998. Influence of salt on the quality of reduced fat Cheddar cheese. J. Dairy Sci. 81:1214-1221.

Modzelewska-Kapituła, M., J. Kłobukowski, L. Kłębukowska, and D. Wiśniewska-Pantak. 2010. The influence of feeding diets containing white cheese, produced with prebiotics and the potentially probiotic Lactobacillus plantarum strain, on the gastrointestinal microflora of rats. Czech J. Food Sci. 28:139-145.

Mortazavian, A. M., M. R. Ehsani, S. Sohrabvandi, and J. A. Reinheimer. 2007. MRS-bile agar: Its suitability for the enumeration of mixed probiotic cultures in cultured dairy products. Milchwissenschaft $62: 270-272$.

Mortazavian, A. M., S. Ghorbanipour, M. A. Mohammadifar, and M. Mohammadi. 2011. Biochemical properties and viable probiotic population of yogurt at different bacterial inoculation rates and incubation temperatures. Philippine Agric. Scientist 94:111-116.

Mortazavian, A. M., R. Khosrokhavar, H. Rastegar, and G. R. Mortazaei. 2010. Effects of dry matter standardization order on biochemical and microbiological characteristics of freshly made probiotic Doogh (Iranian fermented milk drink). Ital. J. Food Sci. 22:98-104.

Muir, D. D., J. M. Banks, and E. A. Hunter. 1996. Sensory properties of Cheddar cheese: Effect of starter type and adjunct. Int. Dairy J. 6:407-423.

Nath, K. R., and R. A. Ledford. 1973. Growth response of Lactobacillus casei variety casei to proteolysis products in cheese during ripening. J. Dairy Sci. 56:710-718.

Nielsen, S. S. 2002. Plasmin system and microbial proteases in milk: Characteristics, roles, and relationship. J. Agric. Food Chem. 50:6628-6634.
Noomen, A. 1978. Activity of proteolytic enzymes in simulated soft cheeses (Meshanger type). 1. Activity of milk protease. Neth. Milk Dairy J. 32:26-48.

Ong, L., A. Henriksson, and N. P. Shah. 2006. Development of probiotic Cheddar cheese containing Lactobacillus acidophilus, Lb. paracasei, Lb. casei and Bifidobacterium spp. and the influence of these bacteria on proteolytic patterns and production of organic acid. Int. Dairy J. 16:446-456.

Ong, L., A. Henriksson, and N. P. Shah. 2007. Chemical analysis and sensory evaluation of Cheddar cheese produced with Lactobacillus acidophilus, Lb. casei, Lb. paracasei or Bifidobacterium sp. Int. Dairy J. 17:937-945.

O'Sullivan, D., R. P. Ross, G. F. Fitzgerald, and A. Coffey. 2000. Investigation of the relationship between lysogeny and lysis of Lactococcus lactis in cheese using prophage-targeted PCR. Appl. Environ. Microbiol. 66:2192-2198.

Özer, B., Y. S. Uzun, and H. A. Kirmaci. 2008. Effect of microencapsulation on viability of Lactobacillus acidophilus LA-5 and Bifidobacterium bifidum BB-12 during Kasar cheese ripening. Int. J. Dairy Technol. 61:237-244.

Pastorino, A. J., C. L. Hansen, and D. J. McMahon. 2003. Effect of salt on structure-function relationships of cheese. J. Dairy Sci. 86:60-69

Ramadan, F. A. M. 1995. Partial replacement of sodium by potassium in the manufacture of Domiati cheese. Egypt. J. Dairy Sci. $23: 259-270$.

Rao, A. V., N. Shiwnarain, and I. Maharaj. 1989. Survival of microencapsulated Bifidobacterium pseudolongum in simulated gastric and intestinal juices. Can. Inst. Food Sci. Technol. J. 22:345-349.

Rasmussen, R. R., and D. M. Barbano. 1987. Influence of potassium chloride on Cheddar cheese moisture, acidity and proteolysis. J. Dairy Sci. 70(Suppl. 1):78 (Abstr.)

Reddy, K. A., and E. H. Marth. 1994. Sensory evaluation of Cheddar cheese made with sodium chloride or mixtures of sodium and potassium chloride. J. Sens. Stud. 9:187-204.

Reinheimer, J. A., P. M. Renzulli, A. C. Rubiolo, N. B. Bailo, and A. G. Binetti. 1997. Effects of sodium chloride and potassium chloride on growth and acid production in thermophilic lactic acid bacteria. Microbiol. Aliment. Nutr. 15:7-15.

Renner, E., and M. H. Abd El-Salam. 1991. Application of Ultrafiltration in the Dairy Industry. Elsevier Science Publishing, London, UK.

Ruegg, M., and B. Blanc. 1981. Influence of water activity on the manufacture and aging of cheese. Pages 791-811 in Water Activity: Influences on Food Quality. Academic Press, New York, NY.

Rychlik, M., R. Warmke, and W. Grosch. 1997. Ripening of Emmental cheese wrapped in foil with and without addition of Lactobacillus casei subsp. casei. III. Analysis of character impact flavour compounds. Lebensm. Wiss. Technol. 30:471-478.

Shafiee, G., A. M. Mortazavian, M. A. Mohammadifar, M. R. Koushki, A. Mohammadi, and R. Mohammadi. 2010. Combined effects of dry matter content, incubation temperature and final $\mathrm{pH}$ of fermentation on biochemical and microbiological characteristics of probiotic fermented milk. African J. Microbiol. Res. 4:1265-1274.

Sharp, M. D., D. J. McMahon, and J. R. Broadbent. 2008. Comparative evaluation of yogurt and low-fat Cheddar cheese as delivery media for probiotic Lactobacillus casei. J. Food Sci. 73:M375M377.

Shihata, A., and N. P. Shah. 2000. Proteolytic profiles of yogurt and probiotic bacteria. Int. Dairy J. 10:401-408

Sousa, M. J., Y. Ardö, and P. L. H. McSweeney. 2001. Advances in the study of proteolysis during cheese ripening. Int. Dairy J. 11:327-345.

Souza, C. H. B., and S. M. I. Saad. 2008. Viability of Lactobacillus acidophilus La-5 added solely or in co-culture with a yoghurt starter culture and implications on physico-chemical and related properties of Minas fresh cheese during storage. Food Sci. Technol. 42:633-640.

Talwalkar, A., and K. Kailasapathy. 2004. Comparison of selective and differential media for the accurate enumeration of strains of Lac- 
tobacillus acidophilus, Bifidobacterium spp. and Lactobacillus casei complex from commercial yoghurts. Int. Dairy J. 14:143-149.

Tamime, A. Y., and J. Kirkegaard. 1991. Manufacture of Feta cheese Industrial. Pages 70-143 in Feta and Related Cheeses. R. K. Robinson and A. Y. Tamime, ed. Ellis Horwood, London, UK.

Tamime, A. Y., R. K. Robinson, and G. Kiers. 2006. Industrial manufacture of Feta-type cheeses. Pages 77-116 in Brined Cheeses. A Y. Tamime, ed. Blackwell, Oxford, UK.

Tamime, A. Y., M. Saarela, A. Korslund Søndergaard, V. V. Mistry, and N. P. Shah. 2005. Production and maintenance of viability of probiotic microorganisms in dairy products. Pages 39-63 in Probiotic Dairy Products. A. Y. Tamime, ed. Blackwell Publishing, Ayr, UK.

Trépanier, G., R. E. Simard, and B. H. Lee. 1991a. Effect of added lactobacilli on composition and texture of Cheddar cheese during accelerated maturation. J. Food Sci. 56:696-700.

Trépanier, G., R. E. Simard, and B. H. Lee. 1991b. Lactic acid bacteria relation to accelerated maturation of Cheddar cheese. J. Food Sci. 56:1238-1240.

Turner, K. W., and D. T. Thomas. 1980. Lactose fermentation in Cheddar cheese and the effect of salt. New Zeal. J. Dairy Sci. $15: 265-276$.
Upadhyay, V. K., P. L. H. McSweeney, A. A. A. Magboul, and P. F. Fox. 2004. Proteolysis in cheese during ripening. Pages 391-433 in Cheese: Chemistry, Physics and Microbiology. Vol. 1. P. Fox, P. McSweeney, T. Cogan, and T. Guinee, ed. Elsevier Academic Press, London, UK.

Vinderola, G., W. Prosello, F. Molinari, D. Ghiberto, and J. A. Reinheimer. 2009. Growth of Lactobacillus paracasei A13 in Argentinian probiotic cheese and its impact on the characteristics of the product. Int. J. Food Microbiol. 135:171-174.

Vinderola, C. G., and J. A. Reinheimer. 1999. Culture media for the enumeration of Bifidobacterium bifidum and Lactobacillus acidophilus in the presence of yoghurt bacteria. Int. Dairy J. 9:497-505.

Visser, S., and G. van den Berg. 2002. The role of proteolytic enzymes in cheese ripening. Pages 6-9 in IDF Bulletin 371. International Dairy Federation, Brussels, Belgium.

Watkinson, P., C. Coker, R. Crawford, C. Dodds, K. Johnston, A McKenna, and N. White. 2001. Effect of cheese pH and ripening time on model cheese textural properties and proteolysis. Int. Dairy J. 11:455-464.

Yılmaztekin, M., B. H. Özer, and A. F. Atasoy. 2004. Survival of Lactobacillus acidophilus LA-5 and Bifidobacterium bifidum BB-02 in white-brined cheese. Int. J. Food Sci. Nutr. 55:53-60. 